\title{
Bibliografický soupis publikací prof. Antonína Bartoňka'
}

\section{Bibliography of Prof. Antonín Bartoněk's Works²}

Varia Punica. Listy filologické, 73, 227.

\section{0}

Funkce řeckých výrazů u ř́mských autorů (Diss. Filosofická fakulta Masarykovy university Brno).

\section{4}

Scheller, M. (1954). Zur Oxytonierung der griechischen Substantive in -ia. (Rev.). Sbornik praci Filozofické fakulty brněnské univerzity, A 2, 106-109.

\section{5}

K problému jazykového míšení v literárním díle. Řečtina a latina u D. Magna Ausonia [Zum Problem der sprachlichen Mischung im literarischen Schaffen. D. Magnus Ausonius]. Sbornik prací Filozofické fakulty brněnské univerzity, D 1, 154-161.

Bogolepov, V. M. (1955). Učebnice latiny pro posluchače mediciny a farmacie. Praha: SPN (Transl. from the Russian by A. Bartoněk, R. Hošek, \& Z. Zlatuška).

Časopis „Word“ (1950). (Rev.). Listy filologické, 78, 1955, 147-149.

Ljandesberg, J. S., \& Golikov, N. N. (1955). Latina pro veterináré Praha: SPN (Transl. from the Russian by A. Bartoněk, \& R. Hošek).

1 Tento soupis prací představuje bibliografii celoživotního díla prof. Antonína Bartoňka a zahrnuje i starší práce, uvedené v soupisech D. Urbanové (1991, Bibliografický soupis prací prof. Antonína Bartoňka. Sbornik praci Filozofické fakulty Brněnské univerzity, E 36, 7-22) a I. Radové (2001-2002, Bibliografický soupis prací prof. Antonína Bartoňka. Sbornik prací Filozofické fakulty Brněnské univerzity, N 6-7, 5-19).

2 The present list of works represents prof. Antonín Bartoněk’s lifelong bibliography and includes also older publications, which have been introduced in the lists by D. Urbanová (1991, Bibliografický soupis prací prof. Antonína Bartoňka. Sbornik praci Filozofické fakulty Brněnské univerzity, E 36, 7-22) and I. Radová (2001-2002, Bibliografický soupis prací prof. Antonína Bartoňka. Sborník prací Filozofické fakulty Brněnské univerzity, $N$ 6-7, 5-19). 


\section{6}

Nynější stav v luštění krétského lineárního písma B [The Present State of Deciphering the Cretan Linear Script B]. Sbornik praci Filozofické fakulty brněnské univerzity, A 4, $108-122$.

Lineární písmo B a hegemonie Řeků na Krétě v pozdní době mínojské [Linear Script B and the Hegemony of the Greeks in Crete in the Late Minoan Period]. Sbornik praci Filozofické fakulty brněnské univerzity, C 3, 145-149.

Rozluštění dalšího z neznámých písem Orientu. Věda a život, 1956(12), 559-562.

„Casus septimus“ a „casus octavus“ v pojetí římských gramatiků [The Latin Grammarians' Conception of the „Seventh“ and of the „Eighth“ Case]. Sbornik praci Filozofické fakulty brněnské univerzity, E 1, 173-182.

Bennett, E. L. (1951). Pylos Tablets: a Preliminary Transcription. Princeton: Princeton Univ. Press. (Rev.). Listy filologické, 79, 1956, 272-273.

Bennett, E. L. (1953). A Minoan Linear B-Index. New Haven: Yale Univ. Press. (Rev.). Listy filologické, 79, 277-278.

Bennett, E. L. (1953). The Mycenae Tablets. (Rev.). Listy filologické, 79, 276-277.

Evans A. J., \& Myres, J. L. (1952). Scripta Minoa, II: The Archives of Knossos. Oxford: Clarendon Press. (Rev.). Listy filologické, 79, 273-276.

Friedrich, J. (1954). Entzifferung verschollener Schriften und Sprachen. Berlin: Springer. (Rev.). Sbornik prací Filozofické fakulty brněnské univerzity, E 1, 203.

Hahn, E. A. (1953). Subjunctive and Optative. New York: American Philological Association. (Rev.). Sbornik praci Filozofické fakulty brněnské univerzity, A 4, 132-134.

Hoffmann, O. (1953). Geschichte der griechischen Sprache, I. Berlin: de Gruyter. (Rev.). Sbornik praci Filozofické fakulty brněnské univerzity, A 14, 134-136.

Niedermann, M. (19534). Précis de phonétique historique du latin. Paris: Klincksieck. (Rev.). Sbornik praci Filozofické fakulty brněnské univerzity, E 1, 196-197.

Nový příspěvek k dějinám gramatického myšlení: Robins, R. H. (1951). Ancient and Medieval Grammatical Theory in Europe. London: Bells. (Rev.). Sbornik praci Filozofické fakulty brněnské univerzity, A 4, 146.

Oksala, P. (1953). Die griechischen Lehnwörter in den Prosaschriften Ciceros. Helsinki: Druckerei der Finn. Literaturges. (Rev.). Sbornik praci Filozofické fakulty brněnské univerzity, D 2, 157-161.

Pisani, V. (1953). Le lingue dell'Italia antica oltre il latino. Torino: Rosenberg \& Sellier. (Rev.). Sbornik prací Filozofické fakulty brněnské univerzity, E 1, 197-198.

Safarewicz, J. (1953). Zarys gramatyki historycznej języka łacińskiego, I. Warszawa: Państw. Wyd. Nauk. (Rev.). Listy filologické, 79, 278-281.

\section{7}

A Contribution to the Problem of the Land Tenure in Ancient Pylos. Sbornik praci Filozofické fakulty brněnské univerzity, E 2, 115-117.

Dvě kapitoly z historie rozluštění lineárního písma B [Two Chapters from the History of Solving the Linear B Script]. Listy filologické, 80, 1957, 1-9.

The Linear B Signs 8-A and 25-A . Remarks on the Problem of "Mycenaean" Doublets. Sbornik praci Filozofické fakulty brněnské univerzity, A 5, 44-62. 
Ernout, A., \& P. Chantraine (1955). Revue de Philologie, de littérature et d'histoire anciennes. (Rev.). Listy filologické, 80(1). 145-146.

Georgiev, V. (1954). Nynešneje sostojanje tolkovanija krito-mikenskich nadpisej. Sofija: Izdanie Bolgarskoj akademii nauk. (Rev.). Archiv orientálni, 25, 676-677.

Georgiev, V. (1955). Slovaŕ krito-mikenskich nadpisej. Sofija: Izdanie Bolgarskoj akademii nauk. (Rev.). Archiv orientální, 25, 678-680.

Georgiev, V. (1955). Vyedenie v čtenije i tolkovanije krito-mikenskich nadpisej. Izvestija Akademiji nauk SSSR, otd. literatury i jazyka, 14, 267-279. (Rev.). Archiv orientální, 25, 677-678.

Georgiev, V. (1956). Dopolnenie k Slovarju krito-mikenskich nadpisej. Sofija: Daržavno Izdat. Nauka i izkustvo. (Rev.). Archiv orientální, 25, 680.

Krahe, H. (1954). Sprache und Vorzeit. Heidelberg: Quelle \& Meyer. (Rev.). Sbornik praci Filozofické fakulty brněnské univerzity, A 5, 145-146.

Nejnovější práce o zemědělských poměrech ve starém Pylu. (Rev.). Sbornik praci Filozofické fakulty brněnské univerzity, E 2, 178-180.

\section{8}

Ještě k jazykové zeměpisné metodě v starořecké dialektologii. Listy filologické, 81, 118-121. K odmítavým kritikám Ventrisova pokusu o rozluštění lineárního písma B [On the Negative Criticism of Ventris' Decipherment of the Linear B Script]. Sbornik prací Filozofické fakulty brněnské univerzity, E 3, 95-102.

Bennet, E. L., Chadwick, J., \& Ventris, M. (1956). Knossos Tablets. London: University of London, Institute of Classical Studies. (Rev.). Archiv orientálni, 26, 682-684.

Bennett, E. L. (1955). The Pylos Tablets. Texts of the Inscriptions Found 1939-1954. Princeton: Princeton University Press. (Rev.). Archiv orientálni, 26, 680-682.

Brandstein, W. (1954). Griechische Sprachwissenschaft, I. Berlin: De Gruyter. (Rev.). Sbornik praci Filozofické fakulty brněnské univerzity, E 3, 144-145.

Francev, J. P. (1958). Dějiny světa (Vol. I). Praha: Státní nakladatelství politické literatury (Transl. from the Russian by A. Bartoněk et al.).

Le colloque international sur les textes mycéniens. Listy filologické, 81, 121-122.

Nynější stav bádání o krétském lineárním písmě A. Listy filologické, 81, 234-238.

Periodika vydávaná londýnským ústavem klasických studií. Sbornik praci Filozofické fakulty brněnské univerzity, E 3, 156-158.

Slabičná písma z východního Středomoří v 2. a 1. tisíciletí př. n. 1. Ročenka Jednoty klasických filologư.

Ventris, M., \& Chadwick, J. (1956). Documents in Mycenaean Greek. Cambridge: University Press. (Rev.). Sbornik praci Filozofické fakulty brněnské univerzity, E 3, 145-148.

Záhadné nápisy z Kanárských ostrovů. Věda a život, 1958(12), 603.

1959

Latina pro posluchače filologických oborů (Vol. I). Praha: Státní pedagogické nakladatelství 1959 (2. ed. 1962).

Die syllabischen Schriften des östlichen Mittelmeerraums. Das Altertum, 5 (Berlin), 16-34.

Die Wortparallelen aude und fone in der archaischen epischen Sprache. Sbornik praci Filozofické fakulty brněnské univerzity, E 4, 67-76. 
Buck, C. D. (1955). Greek Dialects. Chicago: University of Chicago Press. (Rev.). Listy filologické, 82, 140-143.

Cassola, F. (1957). La Ionia nel mondo miceneo. Napoli: Ed. Scientifiche Italiane. (Rev.). Sbornik prací Filozofické fakulty brněnské univerzity, A 4, 140-141.

Grumach, E. (Ed.). (1958). Minoica - Festschrift zum 80. Geburtstag von J. Sundwall. Berlin: AkademieVerlag. (Rev.). Deutsche Literaturzeitung, 80, 12.

Chadwick, J. (1958). Decipherment of Linear B. Cambridge: Cambridge University Press. (Rev.). Vědecké knihy $\check{C} S A V$.

K úkolům sovětské vědy v oboru antických jazyků. Sbornik praci Filozofické fakulty brněnské univerzity, E 4, 144-146.

Konference Výboru pro podporu klasických studií v socialistických státech, Erfurt 1958. (Rev.). Věda a život, 1959(5-6), 366-367.

Konference Výboru pro podporu klasických studií v socialistických státech, Erfurt 1958. (Rev.). Sbornik prací Filozofické fakulty brněnské univerzity, E 4, 142-144 (with L. Vidman).

Nové pramenné práce z oboru mykénských studií. Listy filologické, 82, 301-303.

Pečírka, J., \& Nováková, J. et al. (1959). Antika v dokumentech, 1: Řecko. Praha: SNPL (cooperation).

Ruijgh, C. J. (1957). L'élement achéen dans la langue épique. Assen: Van Gorcum. (Rev.). Sbornik praci Filozofické fakulty brněnské univerzity, E 4, 120-122.

\section{0}

Cestou k naší abecedě [Progress towards the Alphabet]. Věda a život, 1960(4), 210-213.

Zur Problematik der phonematischen Wertung der altgriechischen kurzen Diphtonge. Sbornik prací Filozofické fakulty brněnské univerzity, E 5, 85-88.

III. mezinárodní sjezd klasických filologů v Londýně, září 1959. (Rev.). Sbornik praci Filozofické fakulty brněnské univerzity, E 5, 161-164.

III. mezinárodní sjezd klasických filologů v Londýně, září 1959. (Rev.). Věda a život, 1960(1), 36-37.

Antkovski, F. (1956). La chronologie de la monophtongaison des diphtongues dans les langues indoeuropéenes. Poznań: Państwowe wydawn. naukowe. (Rev.). Sbornik praci Filozofické fakulty brněnské univerzity, E 5, 170-171.

Bennett, E. L. (Ed.). (1958). Mycenae Tablets (Vol. II). Philadelphia: The American Philosophical Society. (Rev.). Archiv orientální, 27, 336-337.

Chadwick, J. (1958). Decipherment of Linear B. Cambridge: Cambridge University Press. (Rev.). Sbornik prací Filozofické fakulty brněnské univerzity, E 5, 135-136.

Grumach, E. (Ed.). (1958). Minoica - Festschrift zum 80. Geburtstag von J. Sundwall. Berlin: AkademieVerlag. (Rev.). Sbornik praci Filozofické fakulty brněnské univerzity, E 5, 164-166.

Landau, O. (1958). Mykenisch-griechische Personennamen. Göteborg: Almqvist \& Wiksell. (Rev.). Sbornik prací Filozofické fakulty brněnské univerzity, E 5, 137-138.

Lejeune, M. (Ed.). (1956). Études mycéniennes. Paris: Centre nat. de la recherche scientifique. (Rev.). Sbornik prací Filozofické fakulty brněnské univerzity, E 5, 167-168.

Lurje, S. J. (1957). Jazyk i kultura mikenskoj Greciji. Moskva: Izdat. Akademii nauk SSSR. (Rev.). Sbornik praci Filozofické fakulty brněnské univerzity, E 5, 134-137.

Strunk, K. (1957). Die sogenannten Äolismen der homerischen Sprache. München: s. n. (Rev.). Sbornik praci Filozofické fakulty brněnské univerzity, E 5, 170-171. 
Thumb, A., \& Scherer, A. (1959). Handbuch der griechischen Dialekte (Vol. II). Heidelberg: Winter. (Rev.). Sbornik praci Filozofické fakulty brněnské univerzity, E 5, 156-158.

Webster, T. B. L. (1958). From Mycenae to Homer. London: Methuen. (Rev.). Sbornik praci Filozofické fakulty brněnské univerzity, E 5, 132-134.

\section{1}

Vývoj konsonantického systému $v$ reckých dialektech [Development of the Consonantal System in Ancient Greek Dialects]. Praha: Státní pedagogické nakladatelství (215 pp.).

Die Äolismen und Achaismen in der homerischen Sprache seit der Ventrisschen Entzifferung der LB-Schrift. In Georgiev, V., \& J. Irmscher (Eds.), Minoica und Homer (pp. 1-9). Berlin: Akademie-Verlag.

K Palmerově kritice Evansova datování knosských tabulek. Listy filologické, 84(2), 325329.

K otázce nářečního zařazení mykénštiny mezi starořecké dialekty [The Most Recent Works on the Classification of Ancient Greek Dialects] (Part I). Listy filologické, 84, 207-211.

Problem of Double $\bar{e}-\bar{o}$ - Sounds in Ancient Greek Dialects. In F. Stiebitz, \& R. Hošek (Eds.), Charisteria Francisco Novotný octogenario oblata (pp. 79-92). Praha: Státní pedagogické nakladatelství.

Remarks to the Chronology of the ei, ou Monophthongization in Greek. Sbornik praci Filozofické fakulty brněnské univerzity, E 6, 135-146.

$2^{\circ}$ colloquio internazionale di studi minoico-micenei, Pavia 1958. (Rev.). Sbornik praci Filozofické fakulty brněnské univerzity, E 6, 288-289.

Archaeology, 13(1). (1960). (Rev.). Listy filologické, 84, 329-330.

Bennett, E. L., Chadwick, J., Ventris, M., \& Householder, F. W. (1959). The Knossos Tablets (2. ed.). London: Institute of Classical Studies. (Rev.). Sbornik praci Filozofické fakulty brněnské univerzity, E 6, 297.

Brugnoli, G. (Ed.). (1960). C. Suetoni Tranquilli praeter Caesarum libros reliquiae, Pars prior: De grammaticis et rhetoribus. Lipsiae: Teubner. (Rev.). Sbornik praci Filozofické fakulty brněnské univerzity, E 6 , 300-301.

Georgijev, V., \& Irmscher, J. (Eds.) (1961). Minoica und Homer: eine Aufsatzsammlung (Deutsche Akademie der Wissenschaften zu Berlin, Schriften der Sektion für Altertumswissenschaft, 29). Berlin: Akademie-Verlag. (Rev.). Sbornik prací Filozofické fakulty brněnské univerzity, E 6, 302.

K nejnovějším názorům o mykénské koiné. Sbornik praci Filozofické fakulty brněnské univerzity, E 6, 277 279.

Kodzu, H. (1960). Greek Grammar. Tokyo. (Rev.). Sbornik praci Filozofické fakulty brněnské univerzity, E 6, 297-298.

Lejeune, M. (1958). Mémoires de la philologie mycénienne. Paris: Centre National de la Recherche Scientifique. (Rev.). Sbornik praci Filozofické fakulty brněnské univerzity, E 6, 279-281.

\section{2}

Der Latein- und Griechischunterricht in der Tschechoslowakischen sozialistischen Republik. Romanitas, 4 (Rio de Janeiro), 369-384.

K míšení latinských a řeckých výrazových prvků v římské literatuře [Zur Mischung griechischer und lateinischer Ausdruckelemente in der römischen Literatur]. Sbornik praci Filozofické fakulty brněnské univerzity, E 7, 43-51. 
K otázce nářečního zařazení mykénštiny mezi starořecké dialekty [The Most Recent Works on the Classification of Ancient Greek Dialects] (Part II). Listy filologické, 85, 342-347.

The Boeotian and Thessalian Narrowings of Long Vowels: A Comparative Study. Sbornik praci Filozofické fakulty brněnské univerzity, A 11, 167-179.

Brandenstein, W. (1959). Griechische Sprachwissenschaft, II: Wortbildung und Formenlehre. Berlin: De Gruyter. (Rev.). Sbornik praci Filozofické fakulty brněnské univerzity, E 7, 127-128.

Chadwick, J. (1959). Linear B: Die Entzifferung der mykenischen Schrift. Göttingen: Vandenhoeck \& Ruprecht. (Rev.). Sbornik prací Filozofické fakulty brněnské univerzity, E 7, 134.

\section{3}

Historie Achchijawy ve světle chetitských dokumentů [The History of Ahhijawa in the Light of the Hittite Documents]. Sbornik praci Filozofické fakulty brněnské univerzity, C 10, 5-16.

K uplatnění nových metod při zkoumání antických jazyků, zejména ve staré řečtině [On the Application of the New Methods to the Study of Latin and Greek]. Listy filologické, 86, 197-206.

Monophonemic Diphthongs in Mycenaean. Minos, 8 (Salamanca), 51-61.

On the Sources of Origin of the Attic-Ionic Changes $a>a$ and $u>\ddot{u}$. Acta Universitatis Carolinae, Philosophica et Historica, Graeco-Latina Pragensia, II, 27-39.

Remarks on the Problem of the Elean Sign A Representing the Proto-Greek $\bar{e}$. Eirene, II, 97-110.

The Development of the Attic-Ionic Long-Vowel System. Sbornik praci Filozofické fakulty brněnské univerzity, E 8, 73-84.

Francev, J. P. (1962). Dějiny světa (Vol. V). Praha: Státní pedagogické nakladatelství politické literatury (Transl. from the Russian by A. Bartoněk et al.).

Nóbrega, V. L. da (1962). Presença do Latim (Vol. 1-3). Rio de Janeiro: INEP. (Rev.). Zprávy Jednoty klasických filologü, 5, 197-199.

Page, D. L. (1959). History and the Homeric Iliad. Berkeley: University of California Press. (Rev.). Sbornik prací Filozofické fakulty brněnské univerzity, E 8, 149-153.

Woodhead, A. G. (1959). The Study of Greek Inscriptions. Cambridge (Mass.): Cambridge University Press. (Rev.). Sbornik praci Filozofické fakulty brněnské univerzity, E 8, 148-149.

\section{4}

Latina pro posluchače filosofické fakulty. Praha: Státní pedagogické nakladatelství (3. ed. 1965; 6. ed. 1990; 11. ed. 2010).

Deset let mykénologie [Ten Years of Mycenaeology]. Listy filologické, 87, 296-309.

Jazykovědná bádání v oblasti věd o antickém starověku. In L. Varcl (Ed.), Antická konference (pp. 47-62). Praha: Československá akademie věd.

Mykénologická bádání. In L. Varcl (Ed.), Antická konference (pp. 63-70). Praha: Československá akademie věd.

Nynější stav v luštění krétského lineárního písma A [The Present State in Deciphering the Cretan Linear Script A]. In G. Hejzlar, \& J. Češka (Eds.), Mnema Vladimír Groh (pp. 197-210). Praha: Státní pedagogické nakladatelství. 
Outline of Phonemic System in Mycenaean Greek. Sbornik praci Filozofické fakulty brněnské univerzity, A 12, 195-209.

The Phonic Evaluation of the $S$ - and Z-Signs in Mycenaean. Sbornik praci Filozofické fakulty brněnské univerzity, E 9, 89-102.

Výuka latiny na vysokých školách. In L. Varcl (Ed.), Antická konference (pp. 113-132). Praha: Československá akademie věd.

Zur sozialökonomischen Struktur der mykenischen Gesellschaft. In L. Welskopf-Henrich (Ed.), Neue Beiträge zur Geschichte der alten Welt, Band I: Alter Orient und Griechenland (pp. 149-162). Berlin: Akademie-Verlag.

\section{5}

Nástin elementárního mykénského hláskosloví a tvarosloví [A Brief Survey of the Mycenaean Phonology and Morphology]. Sbornik praci Filozofické fakulty brněnské univerzity, E 10, 29-60.

On the Application of the Modern Linguistic Methods to the Study of Classical Languages, esp. Greek. Eirene, IV, 123-132.

Bennett, E. L. (Ed.). (1964). Mycenaean Studies. Proceedings of the Third International Colloquium for Mycenaean Studies. Madison (Wis.): University of Wisconsin Press. (Rev.). Sbornik praci Filozofické fakulty brněnské univerzity, E 10, 389-393.

\section{6}

Development of the Long-Vowel System in Ancient Greek Dialects. Praha: Státní pedagogické nakladatelství (2. ed. Amsterdam: A. M. Hakkert 1972).

Divergenz und Konvergenz in der griechischen Dialektologie. Sbornik praci Filozofické fakulty brnènské univerzity, E 11, 83-88.

K otázce prařecké jazykové jednoty [On the Problem of the Proto-Greek Linguistic Unity]. Listy filologické, 89, 225-230.

Mycenaean Koine Reconsidered. In L. R. Palmer (Ed.), Proceedings of the Cambridge Colloquium on Mycenaean Studies (pp. 95-103). Cambridge: Cambridge University Press.

O mykénské kultuře. Věda a život, 1966(1), 28-36.

Od Mykén k Homérovi. Věda a život, 1966(11), 648-654.

Antika a dnešek mezinárodně. Lidová demokracie, 23. 3. 1966.

Antika ještě čeká na objevy. Lidová demokracie, 29. 5. 1966.

Blegen, C. W. (1961). Troy (The Cambridge Ancient History; rev. ed. of Vol. I, Chap. XVIII, XXIV and Vol. 2, Chap. XV, XXI). Cambridge: Cambridge University Press. (Rev.). Sbornik praci Filozofické fakulty brněnské univerzity, E 11, 149-152.

Caskey, J. L. (1964). Greece, Crete and the Aegean Islands in the Early Bronze Age (The Cambridge Ancient History; rev. ed. of Vol. 2, Chap. XXVI). Cambridge: Cambridge University Press. (Rev.). Sbornik prací Filozofické fakulty brněnské univerzity, E 11, 152-154.

Chadwick, J. (1963). The Prehistory of the Greek Language (The Cambridge Ancient History; rev. ed. of Vol. 2, Chap. XXXIX). Cambridge: Cambridge University Press. (Rev.). Sbornik praci Filozofické fakulty brněnské univerzity, E 11, 162-165.

Co Homér nevěděl. Lidová demokracie, 10. 4. 1966. 
Congressus internationalis: Antiquitas Graeco-Romana ac tempora nostra (sekce č. 4), Brno 1966. (Rev.). Sbornik praci Filozofické fakulty brněnské univerzity, E 11, 202-203.

Diskuse o historickém pozadí trójské války. Sbornik praci Filozofické fakulty brněnské univerzity, E 11, 205206.

Fourth International Colloquium on Mycenaean Studies, Cambridge 1965. (Rev.). Sbornik prací Filozofické fakulty brněnské univerzity, E 11, 198.

Kadmos, 1-2. (Rev.). Listy filologické, 89, 437-442.

Matz, F. (1962). Minoan Civilization: Maturity and Zenith (The Cambridge Ancient History; rev. ed. of Vol. 2, Chap. IV, XII). Cambridge: Cambridge University Press. (Rev.). Sbornik prací Filozofické fakulty brněnské univerzity, E 11, 154-156.

O jedné nové vědě [On a New Science]. Literárni noviny, 15. 10. 1966, p. 10.

Stubbings, F. H. (1963). The Rise of Mycenaean Civilization (The Cambridge Ancient History; rev. ed. of Vol. 2, Chap. XIV). Cambridge: Cambridge University Press. (Rev.). Sbornik prací Filozofické fakulty brněnské univerzity, E 11, 156-159.

Stubbings, F. H. (1964). The Expansion of Mycenaean Civilisation (The Cambridge Ancient History; rev. ed. of Vol. 2, Chap. XXII). Cambridge: Cambridge University Press. (Rev.). Sborník prací Filozofické fakulty brněnské univerzity, E 11, 159-161.

Stubbings, F. H. (1965). The Recession of Mycenaean Civilization (The Cambridge Ancient History; rev. ed. of Vol. 2, Chap. XXVII). Cambridge: Cambridge University Press. (Rev.). Sbornik praci Filozofické fakulty brněnské univerzity, E 11, 161-162.

The Cambridge Ancient History (1961-; rev. ed. of Vol. I and II). Cambridge: Cambridge University Press. (Rev.). Sbornik prací Filozofické fakulty brněnské univerzity, E 11, 148-149.

Vilborg, E. (1962). A Tentative Grammar of Mycenaean Greek (Studia graeca et latina gothoburgensia, 9). Göteborg: Elander. (Rev.). Sbornik praci Filozofické fakulty brněnské univerzity, E 11, 165-168.

\section{7}

Antickou Sicílií. Věda a život, 1967(3), 150-163.

Reflections on the Ancient Greek Short-Vowel System. Sbornik praci Filozofické fakulty brněnské univerzity, E 12, 133-151.

Caskey, J. L. (1966). Greece and the Aegean Islands in the Middle Bronze Age (The Cambridge Ancient History; rev. ed. of Vol. 2, Chap. IV). Cambridge: Cambridge University Press. (Rev.). Sbornik praci Filozofické fakulty brněnské univerzity, E 12, 239-241.

Kirk, G. S. (1964). The Homeric Poems as History (The Cambridge Ancient History; rev. ed. of Vol. 2, Chap. XXXIX). Cambridge: Cambridge University Press. (Rev.). Sbornik praci Filozofické fakulty brněnské univerzity, E 12, 241-243.

Stubbings, F. H. (1962). Chronology: Aegean Bronze Age (The Cambridge Ancient History; rev. ed. of Vol. 1, Chap. VI). Cambridge: Cambridge University Press. (Rev.). Sbornik praci Filozofické fakulty brněnské univerzity, E 12, 238-239.

The Cambridge Ancient History (1965-1966; rev. ed. of Vol. I and II, Fasc. 34-35). Cambridge: Cambridge University Press. (Rev.). Sbornik prací Filozofické fakulty brněnské univerzity, E 12, 237-238.

The Mycenaean Symposium of Brno, April 1966. Kadmos, 5, 163-165. 


\section{8}

Studia Mycenaea. Proceedings of the Mycenaean Symposium, Brno April 1966 (Ed. A. Bartoněk). Brno: Universita J. E. Purkyně, Filozofická fakulta.

Chronology of the First Greek Compensatory Lengthening Reexamined. Sbornik praci Filozofické fakulty brněnské univerzity, E 13, 153-162.

Compensatory Lengthening in Mycenaean. Atti e Memorie del $1^{\circ}$ Congresso Internazionale di Micenologia, Roma, 27 settembre - 3 ottobre 1967. (Vol. 2; pp. 757-763). Roma: Ed. dell'Ateneo.

Dialectal Classification of Mycenaean in the Opinion of Various Scholars. In A. Bartoněk (Ed.), Studia Mycenaea (pp. 211-252). Brno: Universita J. E. Purkyně, Filozofická fakulta. Mycenaeological Activity in the Countries of the Eirene Commitee. In A. Bartoněk (Ed.), Studia Mycenaea (pp. 147-151). Brno: Universita J. E. Purkyně, Filozofická fakulta.

On Greek Dialectology after the Decipherment of Linear B. In A. Bartoněk (Ed.), Studia Mycenaea (pp. 37-51). Brno: Universita J. E. Purkyně, Filozofická fakulta.

Heubeck, A. (1966). Aus der Welt der frühgriechischen Lineartafeln. Göttingen: Vandenhoeck \& Ruprecht. (Rev.). Sbornik praci Filozofické fakulty brněnské univerzity, E 13, 220-222.

Ruijgh, C. J. (1967). Études sur la grammaire et le vocabulaire du grec mycénien. Amsterdam: Hakkert. (Rev.). Minos, 9 (Salamanca), 167-170.

\section{9}

Zlatá Egeis. Praha: Mladá fronta (370 pp.).

Mykénologická anketa a její výsledky [The Mycenological Inquiry of Brno and its Results]. Sbornik praci Filozofické fakulty brněnské univerzity, E 14, 33-44.

Coleman, R. (1963). The Dialect Geography of Ancient Greece. Transactions of the Philological Society, 61, 58-126. (Rev.). Sbornik praci Filozofické fakulty brněnské univerzity, E 14, 287-288.

Gallavotti, C. et al. (Eds.). (1961-1969). Incunabula Graeca Vol. I-XXX. Roma: Ist. di Studi sulle Civiltà dell'Egeo e del Vicino Oriente. (Rev.). Sbornik prací Filozofické fakulty brněnské univerzity, E 14, $285-287$.

1970

Attic-Ionic Dialects Reclassified. Sbornik prací Filozofické fakulty brněnské univerzity, E 15, $149-157$.

\section{1}

Das Ostargolische in der räumlichen Gliederung Griechenlands. In R. Schmitt-Brandt (Ed.), Donum Indogermanicum. Festgabe für Anton Scherer zum 70. Geburtstag (pp. 118122). Heidelberg: Winter.

Greek Dialects in the Second Millennium B. C. Eirene, IX, 49-67.

O egejských písmech a mykénské civilizaci [On Aegean Scripts and Mycenaean Civilization]. Universitas, 4(1), 21-40.

On the Greek Phonemic (Sub)systems. Sbornik praci Filozofické fakulty brněnské univerzity, E 16, 243-252.

Boardma, J. (1968). The Greeks overseas (Repr.). Harmondsworth: Penguin Books. (Rev.). Sbornik praci Filozofické fakulty brněnské univerzity, E 16, 270.

Cook, J. M. (1965). The Greeks in the East. New impression. London: Thames and Hudson. (Rev.). Sbornik prací Filozofické fakulty brněnské univerzity, E 16, 269. 
Crossland, R. A. (1967). Immigrants from the North (The Cambridge Ancient History; rev. ed. of Vol. I, II, Fasc. 60). Cambridge: Cambridge University Press. (Rev.). Sbornik prací Filozofické fakulty brněnské univerzity, E 16, 266-268.

Woodhead, A. G. (1962). The Greeks in the West. London: Praeger. (Rev.). Sbornik praci Filozofické fakulty brněnské univerzity, E 16, 269-270.

1972

Classification of the West Greek Dialects at the Time about 350 B. C. Praha: Academia; Amsterdam: A. M. Hakkert (238 pp.).

Ancient Greek Long-Vowel Systematic Development in a Short Survey for the Didactical Purposes. Sbornik praci Filozofické fakulty brněnské univerzity, E 17, 65-81.

Erupce vulkánu na Théře a konec mínojské civilizace [The Eruption of the Volcano on Thera and the End of Minoan Civilisation]. Sbornik praci Filozofické fakulty brnènské univerzity, E 17, 103-118.

Relevance of the Linear B Linguistic Phenomena for the Classification of Mycenaean. In M. S. Ruiperez (Ed.), Acta Mycenaea (Minos, N.S. 12; pp. 329-345). Salamanca: Universidad de Salamanca.

The Brno Inquiry into the Problems of the Dialectal Classification of Mycenaean. In M. S. Ruiperez (Ed.), Acta Mycenaea (Minos, N.S. 12; pp. 346-360). Salamanca: Universidad de Salamanca.

Palmer, L. R., \& Chadwick, J. (Eds.). (1966). Proceedings of the Cambridge Colloquium on Mycenaean Studies. Cambridge: Cambridge University Press. (Rev.). Eirene, X, 119-121.

1973

Cuičebnice latinské syntaxe. Praha: Státní pedagogické nakladatelství (with B. Mouchová, \& E. Kamínková).

Die Koine-Formationen in der frühhellenistischen Periode. In P. Oliva, \& J. Burian (Eds.), Soziale Probleme im Hellenismus und im römischen Reich. Konferenz Liblice 1972 (pp. 235243). Praha: С̆SAV.

Greek Dialects of Archaic Sicily: Their Integration Tendencies. Graecolatina et Orientalia. Zbornik Filozofickej fakulty Univerzity Komenského, 5, 71-89.

Svoboda, L., Varcl, L., \& Vidman, L. (Eds.). Encyklopedie antiky. Praha: Academia (120 headwords).

The Place of the Dorians in the Late Helladic World. In R. A. Crossland, \& A. Birchall (Eds.), Bronze Age Migrations in the Aegean (pp. 305-311). London: Duckworth.

\section{4}

Die altgriechische Lautlehre im Lichte des Mykenischen. Sbornik praci Filozofické fakulty brněnské univerzity, E 18-19, 1973-1974, 217-224.

1975

Greek Dialects of Ancient Apennine Peninsula. In J. Češka (Ed.), Classica atque Mediaevalia Jaroslao Ludvikovský octogenario oblata (pp. 17-36). Brno: Universita J. E. Purkyně. 
On the Mycenaean Greek Etymologies. In Actes de la XIIe Conférence Internationale d'Études Classiques 'Eirene', Cluj-Napoca, 2-7 octobre 1972 (pp. 703-708). Bucureşti-Amsterdam.

Vývoj latiny a její vztah k jiným jazykům [Latin and its Relations to Other Languages]. Cizi jazyky ve škole, 18, 1974-1975, 105-114.

\section{6}

Odysseové na mořich historie [Odysseus's on the Seas of History]. Praha: Mladá fronta. Antické sochy z mořského dna. Věda a život, 1976(1), 16-19.

\section{7}

Světem starých Řek ن [Through the World of the Ancient Greeks]. Praha: Orbis.

Die kulturelle Ausstrahlung der ägäischen Schriften in die Nachbarländer. Slovenská archeológia, 25, 391-431.

Rozmach a pád mykénských států ve světle lineárních dokumentů [The Flourish and Fall of the Mycenaean States in the Light of the Linear Documents]. Sbornik praci Filozofické fakulty brněnské univerzity, E 22-23, 1978-1979, 193-205.

Zu den Beziehungen des ägäischen, balkanischen und karpatischen Raumes in der mittleren Bronzezeit und die kulturelle Ausstrahlung der ägäischen Schriften in die Nachbarländer. Slovenská archeológia, XXV(2), 371-432 (with J. Vladár).

XIV. konference Komitétu Eiréné v Jerevanu, květen 1976. (Rev.). Sbornik praci Filozofické fakulty brněnské univerzity, E 22-23, 1977-1978, 297-299.

Hood, S. (1971). The Minoans: Crete in the Bronze Age (Ancient People and Places). London: Thames and Hudson. (Rev.). Sbornik prací Filozofické fakulty brněnské univerzity, E 22-23, 1977-1978, 292-293.

\section{8}

On the Chronology in the Prehistory of Greek Language. Eirene, 16, 41-50.

Expedice Egeis. Brněnský večernik, 11. 8. 1978.

1979

Greek Dialects between 1000 and 300 B. C. Studi Micenei ed Egeo-Anatolici, 20 (Roma), 113-130.

Labioveláry v mykénské řečtině [Labiovelars in Mycenaean]. Sbornik praci Filozofické fakulty brněnské univerzity, A 27, 113-123.

Převrat v starořecké dialektologii? [A Revolution in the Greek Dialectology?]. Sbornik praci Filozofické fakulty brněnské univerzity, E 24, 17-34.

Vyjádření jistotní modality v latině ve srovnání s češtinou a němčinou [Die Ausdrucksmittel der Gewißheitsmodalität im Lateinischen im Vergleich mit dem Tschechischen und Deutschen]. Slovo a slovesnost, 40, 185-190.

Expedice Egeis 1978, výsledky. 100+1, Zahraniční zajímavost, 1979(5), 30-35.

Garcia-Ramón, J. L. (1975). Les origines postmycéniennes du groupe dialectal éolien: étude linguistique. Salamanca: Universidad de Salamanca. (Rev.). Sbornik prací Filozofické fakulty brněnské univerzity, E 24, 142-143.

López Eire, A. (1969). Tres cuestiones de dialectología griega. Salamanca: Colegio Trilingüe de la Universidad. (Rev.). Sbornik praci Filozofické fakulty brněnské univerzity, E 24, 144-145. 
López Eire, A. (1970). Innovaciones del jonico-atico (Vocalismo). Salamanca: Universidad. (Rev.). Sbornik praci Filozofické fakulty brněnské univerzity, E 24, 144-145.

López Eire, A. (1972-1973). Los Jonios y el Jónico-Ático. Zephyrus, 23-24. (Rev.). Sbornik prací Filozofické fakulty brněnské univerzity, E 24, 144-145.

López Eire, A. (1974). En busca de la situación dialectal del jónico-ático. In Simposio internacional de colonizaciones (pp. 247-278). Barcelona: Dip. Provincial de Barcelona, Inst. de Prehistoria y Arqueología. (Rev.). Sbornik prací Filozofické fakulty brněnské univerzity, E 24, 144-145.

López Eire, A. (1978). Problematica actual de la dialectología griega. In Actas del V Congreso Español de Estudios Clásicos, Madrid, 1974. Madrid: Sociedad Española de Estudios Clásicos. (Rev.). Sbornik praci Filozofické fakulty brněnské univerzity, E 24, 144-145.

Lupaş, L. (1972). Phonologie du Grec attique. Paris: Mouton. (Rev.). Sbornik prací Filozofické fakulty brněnské univerzity, E 24, 149-150.

Matz, F., \& Buchholz, H.-G. (Eds.). (1968). Archaeologia Homerica: Die Denkmäler und das frühgriechische Epos im Auftrage des Deutschen archäologischen Instituts. Göttingen: Vandenhoeck \& Ruprecht. (Rev.). Sbornik prací Filozofické fakulty brněnské univerzity, E 24, 145.

Plachetnicí z Istanbulu do Pirea. Brněnský večernik, 18. 3., 23. 3., 30. 3., 6. 4. and 13. 4. 1979.

Sommerstein, A. H. (1973). The Sound Pattern of Ancient Greek. Oxford: Basil Blackwell. (Rev.). Sbornik prací Filozofické fakulty brněnské univerzity, E 24, 150-151.

Teodorsson, S.-T. (1974). The Phonemic System of the Attic Dialect 400-340 B. C. Göteborg: Acta Univ. Gothoburgensis. (Rev.). Sbornik prací Filozofické fakulty brněnské univerzity, E 24, 150.

\section{0}

Koncepce větné modality a možnost jejího uplatnění v latině a řečtině [Die Auffassung der Satzmodalität und ihre Ausnutzung im Lateinischen und Griechischen]. In H. Kurzová (Ed.), Moderni lingvistika a klasické jazyky (pp. 63-72). Praha: Kabinet pro studia řecká, římská a latinká ČSAV.

Substantiva a adjektiva souhláskových kmenů 3. deklinace v mykénské řečtině [The Substantives and Adjectives of the $3^{\text {rd }}$ Declension in Mycenaean Greek]. Sbornik praci Filozofické fakulty brněnské univerzity, E 25, 199-223.

Deger-Jalkotzy, S. (1977). Fremde Zuwanderer im spätmykenischen Griechenland. Zu einer Gruppe handgemachter Keramik aus den Myk. III. C Siedlungsschichten von Aigeira. Wien: Verlag der Österreichischen Akademie der Wissenschaften. (Rev.). Sbornik praci Filozofické fakulty brněnské univerzity, E 25, 307-308.

Edice thébských tabulek lineárního písma B. Sbornik praci Filozofické fakulty brněnské univerzity, E 25, 312-313.

Heubeck, A. (1979). Schrift. Göttingen: Vandenhoeck \& Ruprecht. (Rev.). Sbornik prací Filozofické fakulty brněnské univerzity, E 25, 308-311.

Leží Pylos vedle Pylu? 100+1, Zahraniční zajímavost, 1980(7), 30-33.

Press, L. (1978). Pożegnanie z Minosem: Z notatnika podróży w antyczną przeszłość Sycylii. Wrocław: Ossolineum. (Rev.). Sbornik praci Filozofické fakulty brněnské univerzity, E 25, 313.

Schachermeyer, F. (1976). Die ägaische Frühzeit: Forschungsbericht über die Ausgrabungen im letzten Jahrzehnt und über ihre Ergebnisse für unser Geschichtsbild, 1: Die vormykenischen Perioden des griechischen Festlandes und der Kykladen; 2: Die mykenische Zeit und die Gesittung von Thera. 
Wien: Verlag der Österreichischen Akademie der Wissenschaften. (Rev.). Sborník prací Filozofické fakulty brněnské univerzity, E 25, 311-312.

Teodorsson, S.-T. (1974). The Phonemic System of the Attic Dialect 400-340 B. C. Lund-Göteborg: Acta Univ. Gothoburgensis. (Rev.). Sbornik praci Filozofické fakulty brněnské univerzity, E 25, 315-316.

Teodorsson, S.-T. (1977). The Phonology of Ptolemaic Koine. Lund-Göteborg: Acta Univ. Gothoburgensis. (Rev.). Sbornik prací Filozofické fakulty brněnské univerzity, E 25, 315-316.

Warren, P. (1975). The Aegean Civilizations. Oxford: Elsevier. (Rev.). Sbornik praci Filozofické fakulty brněnské univerzity, E 25, 306-307.

\section{1}

Die ägäischen Schriften in ihren kleinasiatischen Zusammenhängen. Sbornik praci Filozofické fakulty brněnské univerzity, E 26, 59-66.

Hiller, S., \& Panagl, O. (1976). Die frühgriechischen Texte aus mykenischer Zeit: Zur Erforschung der Linear B-Tafeln. Darmstadt: Wissenschaftliche Buchgesellschaft. (Rev.). Sbornik prací Filozofické fakulty brněnské univerzity, E 26, 165.

Schmitt, R. (1977). Einführung in die griechischen Dialekte. Darmstadt: Wissenschaftliche Buchgesellschaft. (Rev.). Sbornik praci Filozofické fakulty brněnské univerzity, E 26, 165-166.

Současné corpus dokladů lineárního písma B. Sbornik prací Filozofické fakulty brněnské univerzity, E 26, 163-165.

1982

Substantiva a adjektiva samohláskových kmenů 3. deklinace v mykénské řečtině [The Vocalic and Diphthongal Stems of the $3^{\text {rd }}$ Declension in Mycenaean Greek]. Sbornik praci Filozofické fakulty brněnské univerzity, E 27, 223-235.

\section{3}

Zlaté Mykény [Golden Mycenae]. Praha: Panorama.

Das böotische Theben auf einer ägyptischen Namensliste? Sbornik praci Filozofické fakulty brnènské univerzity, E 28, 201-204.

Klasifikace starořeckých dialektů v novém pojetí [The Classification of Ancient Greek Dialects - a Rearrangement]. Sbornik praci Filozofické fakulty brněnské univerzity, E 28, 205-218.

The Linear B Texts and Their Quantitative Evaluation. In A. Heubeck, \& G. Neumann (Eds.), Res Mycenaeae: Akten des VII. internationalen mykenologischen Colloquiums in Nürnberg vom 6.-10. April 1981 (pp. 15-27). Göttingen: Vandenhoeck \& Ruprecht.

The Main Period of Early Greek Linguistic Development. In P. Oliva, \& A. Frolíková (Eds.), Concilium Eirene XVI. Proceedings of the 16. International Eirene Conference, Prague, 31.8. - 4.9.1982 (Vol. 3; pp. 67-74). Praha: Kabinet pro studia řecká, římská a latinská ČSAV.

Zur Datierung der Linear-B-Texte aus dem Palastarchiv in Knossos. Listy filologické, 106, $138-141$.

Helck, W. (1979). Die Beziehungen Ägyptens und Vorderasiens zur Ägäis bis zum 7. Jahrhundert v. Chr. Darmstadt: Wissenschaftliche Buchgesellschaft. (Rev.). Sbornik praci Filozofické fakulty brněnské univerzity, E 28, 320-323. 


\section{4}

Periodizace raného řeckého jazykového vývoje [The Main Periods of Early Greek Linguistic Development]. Sbornik praci Filozofické fakulty brněnské univerzity, E 29, 201-207.

The Consonantal Declension in Mycenaean. In J. Harmatta (Ed.), Actes du VII Congrès de la Fédération Internationale des Associations d'Études Classiques (Vol. II; pp. 491-497). Budapest: Akad. Kiadó.

\section{5}

Řecko, Turecko, Kypr [Greece, Turkey, Cyprus]. Praha: Olympia (with D. Bartoňková, \& J. Sopouch; 2. ed. 1990 ibidem).

Studium staré rečtiny, latiny a středověké latiny. Geneze antických jazyků a jejich lingvistická charakteristika v konfrontaci s modernimi jazyky (Final report, manuscript). Brno: Univerzita J. E. Purkyně, Filozofická fakulta (with E. Marečková, Č. Prutký, H. Reichová, \& H. Kurzová).

Věcné ideogramy v mykénském lineárním písmu B [Die Sachideogramme in der mykenischen Linear-B-Schrift]. Sbornik praci Filozofické fakulty brněnské univerzity, E 30, 113-124.

\section{6}

Absolute and Relative Chronology in the Early History of the Greek Language (resumé). Bulletin of the Institute of Classical Studies, 33, 141.

Die eteokretischen Inschriften von Kreta im Vergleich mit den griechisch-kretischen. In A. Etter (Ed.), O-o-pe-ro-si: Festschrift für Ernst Risch zum 75. Geburtstag (pp. 901-907). Berlin-New York: W. de Gruyter.

Klassifizierung der Linear-B Ideogramme. In Die Antike und Europa: Zentrum und Peripherie in der antiken Welt. 17. internationale Eirene-Konferenz, Berlin, 11. bis 15. 8. 1986. Berlin: Akademie der Wissenschaften der DDR.

Možnosti a meze starořecké dialektologie [Prospects and Limitations of the Dialectological Study of Ancient Greek]. Sbornik praci Filozofické fakulty brněnské univerzity, E 31, 139-159.

Repetitorium doložení egejských lineárních písem A a B [Repetitorium der ägäischen Linear A und Linear B Belege]. Zprávy Jednoty klasických filologů, 28-29, 1986-1987, 8-19.

\section{7}

Itálie, San Marino, Vatikánský stát, Maltská republika (Travel guide). Praha: Olympia (with D. Bartoňková et al.; 2. ed. 1990 ibidem).

Latina pro posluchače filozofické fakulty (5. ed.). Praha: Státní pedagogické nakladatelství (6. ed. 1990).

Prehistorie a protohistorie ř eckých dialekti̊ [The Prehistory and Protohistory of the Greek Dialects]. Brno: Univerzita J. E. Purkyně.

Př́mořským světem Helady. Brno: Blok (with D. Bartoňková).

On the Prehistory of Ancient Greek. Studi Micenei ed Egeo-Anatolici, 26 (Roma), 7-22.

On the Sources of Juxtavocalic $s$ in Mycenaean. In P. Ilievski, \& L. Crepajac (Eds.), Tractata Mycenaea, Proceedings of the $8^{\text {th }}$ International Colloquium on Mycenaean Studies, 
held in Ohrid, 15-20 September 1985 (pp. 41-48). Skopje: The Macedonian Academy of Sciences and Arts.

Pádový systém v mykénštině [The System of the Mycenaean Cases]. Sbornik praci Filozofické fakulty brnènské univerzity, E 32, 121-126.

Řecký zázrak začal v Mykénách (interview). Věda a život, 5, 324-327 (with Z. Ledererová). The Ancient Languages of the Aegean Area (paper presented at The $6^{\text {th }}$ International Con-

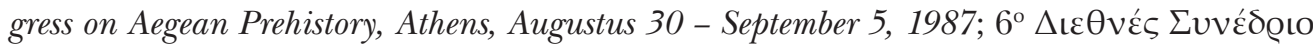

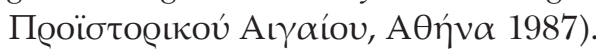

The Vocalic and Diphthongal Stems of $3^{\text {rd }}$ Declension in Mycenaean. In J. T. Killen (Ed.), Studies in Mycenaean and Classical Greek. Presented to John Chadwick (Minos, N. S. 20/22; pp. 61-68). Salamanca: Univ. de Salamanca.

Intervention à la conférence de S.-T. Teodorsson. In Actes de la première Rencontre internationale de dialectologie grecque. Colloque organisé par le C. N. R. S. (Verbum, 10; p. 209). Nancy: Presses universitaires de Nancy.

Kongres boiótských studií. Universitas, 1987(2), 88-90.

\section{8}

Klasifikace latinských vedlejších vět [Klassifizierung der lateinischen Nebensätze]. Sbornik praci Filozofické fakulty brněnské univerzity, A 36, 155-160.

První české gymnázium v Brně [Das erste tschechische Gymnasium in Brünn]. Universitas. Revue Univerzity J. E. Purkyně v Brně, 1988(1), 23-27.

Substantiva 1. deklinace v mykénské řečtině [Substantives of the $1^{\text {st }}$ Declension in Mycenaean Greek]. Sbornik praci Filozofické fakulty brněnské univerzity, E 33, 21-32.

The Name of Thebes in the Documents of the Mycenaean Era. Minos, 23, 39-46.

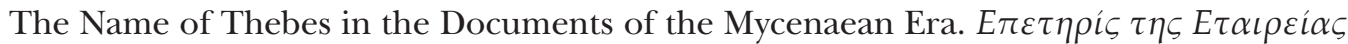

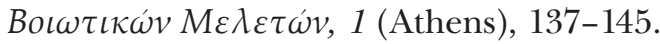

Théra - Santorin. Věda a život, 1988(6), 101-107.

Dubois, L. (1986). Recherches sur le dialecte arcadien. Louvain-la-Neuve: Cabay. (Rev.). Kratylos, 33, 104-109.

Kongres egejských studií v Athénách. Universitas, 1988(2), 75-77.

Mykénologické kolokvium 17. mezinárodní konference Eirene, Berlín (NDR), 11.-15. 8. 1986. Sbornik praci Filozofické fakulty brněnské univerzity, E 33, 194-195.

The Eight International Colloquium on Mycenaean Studies, Ochrid 16.-22. 9. 1985. Sbornik praci Filozofické fakulty brněnské univerzity, E 33, 191-194.

1989

Czechoslovakia [Classical Studies; A Bibliographical Appendix]. In G. Arrighetti et al. (Eds.), La filologia greca e latina nel secolo XX. Atti del congresso internazionale. Roma, Consiglio Nazionale delle Ricerche, 17-21 settembre 1984 (Vol. II; pp. 885-908). Pisa: Giardini.

Il patrimonio lessicale miceneo: Aspetti e problemi. Studi Micenei ed Egeo-Anatolici, 27 (Roma), 131-150 (with D. Marcozzi, P. Peňáz, A. Sacconi, E. Scafa, \& M. Sinatra).

Latinské futurum exactum - vyjadřovací prostředek jistotní modality? [Das lateinische Futurum exactum - ein Ausdrucksmittel der Gewissheitsmodalität?]. Sbornik praci Filozofické fakulty brněnské univerzity, A 37-38, 1989-1990, 157-160. 
Tak to vidím já: Lingua Latina semper viva. Universitas. Revue Univerzity J. E. Purkyně v Brně, 1989(2), 47-49 (with S. Žaža).

1990

Itálie, San Marino, Vatikán (Travel guide). Praha: Olympia (with D. Bartoňková, M. Ludvík, F. Přeučil et al.).

Jmenná flexe v mykénštině [Nominalflexion im Mykenischen]. Listy filologické, 113(4), 261-271.

Makaronská poezie. Echo Latina, 1990(1), 13-16.

Pozdrav něžné revoluci. Echo Latina, 1990(1), 64.

\section{1}

Grundzüge der altgriechischen mundartlichen Frühgeschichte (Innsbrucker Beiträge zur Sprachwissenschaft, 50). Innsbruck: Institut für Sprachwissenschaft der Universität Innsbruck.

Computer a klasická filologie [A Computer in Classical Philology]. Echo Latina, 1991(1), 11-17.

Die Erforschung des Verhältnisses des mykenischen Griechisch zur homerischen Sprachform. In J. Latacz (Ed.), Zweihundert Jahre Homer-Forschung. Rückblick und Ausblick (Kolloquium Rauricum, II; pp. 289-310). Stuttgart: Teubner.

L'evoluzione dei dialetti greci nella dimensione geografica delle età oscure. In D. Musti et al. (Eds.), La transizione dal Miceneo all'alto arcaismo. Dal palazzo alla città. Atti del Convegno Internazionale, Roma, 14-19 marzo 1988 (pp. 241-250). Roma: Consiglio Nazionale delle Ricerche.

\section{2}

History and Bibliography of Classical Scholarship in Czecho-Slovakia, 1900-1987. Part I. The Classical Bulletin, 68(1), 21-62. [See also Part II. in G. Arrighetti et al. (Eds.), La filologia greca e latina nel secolo XX. Atti del Congresso Internazionale, Roma 1984 (Vol. II; pp. 885-908). Pisa: Giardini 1989].

Mycenaean Vocabulary in a Morphological Classification. In F. Létoublon (Ed.), La langue et les textes en grec ancien. Actes du colloque Pierre Chantraine, Grenoble 5-8 Septembre 1989 (pp. 139-150). Amsterdam: J. C. Gieben.

Písemné památky předřeckých jazyků staré Egeidy [On the Written Documents in Pre-Greek Aegean Languages]. Sbornik praci Filozofické fakulty brněnské univerzity, E 37, 115-124.

Schriftlich bezeugte nichtgriechische Sprachen im altägäischen Raum. Eirene, 28 (1992) 5-24. The Lexical Stock of Mycenaean Greek. In J.-P. Olivier (Ed.), Mykenaïka. Actes du IXe Colloque International sur les Textes Mycéniens et Égéens, Athènes, 2-6 Octobre 1990 (pp. 19-56). Athènes: École Française d'Athènes.

Jeffery, L. H. (1990). The Local Scripts of Archaic Greece (rev. edition with a supplement by A. W. Johnston). Oxford: Clarendon Press. (Rev.). Sbornik praci Filozofické fakulty brněnské univerzity, E 37, 202-203. 
1993

Kulturführer: Waldviertel - Weinviertel - Südmähren. Wien: F. Deuticke (ed. with B. Beneš, W. Müller-Funk, \& F. Polleroß; 2. ed. 1996 ibidem).

Latinská syntaktická cvičeni: Se slovnikem. Praha: Karolinum (with J. Janda, E. Kamínková, E. Kutáková, \& B. Mouchová; Reprint 1997, 3. ed. 2004).

Řecko. Průvodce do zahraniči (Travel guide). Praha: Olympia (with D. Bartoňková, \& J. Rubín; 2. ed. 1998, 3. ed. 2001, 4. ed. 2005 ibidem).

Řim. Prưvodce do zahranič́ (Travel guide). Praha: Olympia (with D. Bartoňková, Z. Thoma et al.).

Brněnská klasická filologie na cestě ze středoevropské izolace (1919-1939). In M. Jelínek (Ed.), Brněnská věda a uměni meziválečného obdobi (1918-1939) v evropském kontextu. Sbornik př́spěvků z konference konanév rámci oslav 750. výroči uděleni městských práv Brnu ve dnech 22.-25. zář́ 1993 (pp. 59-63). Brno: Masarykova univerzita.

Die älteste griechische Inschrift in Italien? (Gabii, ca. 770 v. Chr.). Listy fllologické 116(2), 198-200.

Die Entstehung und Ausstrahlung des griechischen Alphabets im östlichen und mittleren Mittelmeerraum im 8.-6. Jh. v. Chr. Sbornik prací Filozofické fakulty brněnské univerzity, E 38, 119-129.

Le lingue egee non-greche nel II e I millennio. Quaderni dell'Istituto di Glottologia, 5, 33-46.

Le lingue egee non-greche. In R. B. Finazzi et al. (Eds.), Lingue e culture in contatto nel mondo antico e altomedievale. Atti dell'VIII Convegno internazionale di linguisti, Milano, 10-12 settembre 1992 (pp. 231-246). Brescia: Paideia.

Prospects and Limitations of the Dialectological Study of the Early Stages of Ancient Greek. In: E. Crespo, J. L. García Ramón, \& A. Striano (Eds.), Dialectologica Graeca (pp. 17-22). Madrid: Univ. Autónoma de Madrid.

Semantic Distribution of the Mycenaean Substantives. Listy filologické, 116(2), 97-108.

1994

Severni Jadran: Itálie a Benátky. Jindřichův Hradec: Globus (with D. Bartoňková).

Le iscrizioni Greche più arcaiche di Ischia. Sbornik prací Filozofické fakulty brněnské univerzity, E 39, 113-117.

Řečtina a etruština na olověné destičce z jižní Francie. Echo Latina, 1994(1), 8-10.

Venetské nápisy v jižním Mad’arsku? Echo Latina, 1994(1), 8.

1995

Die ältesten griechischen Inschriften von Pithekoussai (2. Hälfte des VIII. bis 1. Hälfte des VI. Jh.). Die Sprache, 37(2), 129-231 (with G. Buchner).

[sub Czechoslovakia]. In V. Bers, \& G. Nagy (Eds.), The Classics in East Europe: Essays on the Survival of a Humanistic Tradition. Annual Meeting of the American Philological Association, Chicago, 28 December 1991 (pp. 34-43). Worcester (Mass.): American Philological Association. 


\section{6}

Das lateinische Vokalsystem. In A. Bammesberger, \& F. Heberlein (Eds.), Akten des VIII. internationalen Kolloquiums zur lateinischen Linguistik, Eichstätt 1995 (pp. 117-124). Heidelberg: Univ.-Verlag Winter.

Die ältesten griechischen Inschriften von Pithekoussai. Sborník praci Filozofické fakulty brněnské univerzity, $N$ 1, 7-11.

Literacy in Archaic Latium. In H. Rosén (Ed.), Aspects of Latin, Papers from the Seventh International Colloquium on Latin Linguistics, Jerusalem, 19-23 April 1993 (pp. 19-26). Innsbruck: Institut für Sprachwissenschaft der Universität Innsbruck.

The Mycenaean Language and Dialect. In E. de Miro et al. (Eds.), Atti e Memoire del Secondo Congresso Internazionale di Micenologia, Roma-Napoli, 14-20 ottobre 1991 (pp. 7-23). Roma: Gruppo Editoriale Internazionale.

Za profesorem Janáčkem. Sbornik praci Filozofické fakulty brněnské univerzity, $N$ 1, 111113.

1997

Itálie, San Marino, Vatikán (Travel guide). Praha: Olympia (with D. Bartoňková).

Česká klasická studia po r. 1918. In Mezinárodni vědecká konference na pamět 50. výroči úmrtí českého klasického filologa a překladatele Otmara Vaňorného (pp. 35-49). Vysoké Mýto: Okresní muzeum.

Das Alphabet der archaischen griechischen Inschriften von Pithekoussai. In S. Evangelisti et al. (Eds.), Preatti: XI Congresso Internazionale di Epigrafia Greca e Latina, Roma, 18-24 settembre 1997 (pp. 23-26). Roma: Edizioni Quasar.

\section{8}

Řecké ostrovy. Průvodce do zahraničı (Travel guide). Praha: Olympia (with D. Bartoňková; 2. ed. 2002 ibidem).

Die hocharchaischen griechischen Inschriften aus Pithekoussai (Ischia). In N. Dimoudis, \& A. Kyriatsoulis (Eds.), Die Geschichte der hellenischen Sprache und Schrift: Bruch oder Kontinuität? Proceedings of a conference held 3-6 oct. 1996 in Ohlstadt (pp. 159-173). Altenburg: Verlag für Kultur und Wissenschaft.

Formování jazykové situace v předhistorické a protohistorické Itálii: diachronický pohled. Sbornik prací Filozofické fakulty brněnské univerzity, N 3-4, 1998-1999, 29-38.

Il miceneo ed il greco alfabetico: dai fenomeni ben conosciuti alle coerenze ed alle differenze meno evidenti. In L. Melazzo (Ed.), Continuità e discontinuità nella storia del greco. Atti del Convegno della Società Italiana di Glottologia, Palermo, 24-26 ottobre 1994 (pp. 61-71). Pisa: Istituti editoriali e poligrafici internazionali.

Průvodce krajem a jeho kulturou: Waldviertel, Weinviertel, Jižni Morava. Břeclav: Moraviapress (ed. with B. Beneš, W. Müller-Funk, \& F. Polleroß; Transl. from the German edition Kulturführer: Waldviertel - Weinviertel - Südmähren. Wien: F. Deuticke 1993; 2. ed. 1996 ibidem). 
Das Alphabet der archaischen griechischen Inschriften von Pithekoussai. In Atti dell' XI Congresso Internazionale di Epigrafia Greca e Latina, Roma, 18-24 settembre 1997 (pp. 177-181). Roma: Edizioni Quasar.

Europa und die Tradition der Antike. In J. Fukáč et al. (Eds.), The Crossroads of European Culture, Brno 1998 (pp. 491-496). Brno: University of Technology - VUTIUM Press Brno.

Le iscrizioni greche arcaiche dei secoli VIII e VII da Ischia. In A. C. Cassio (Ed.), Katà diálekton: Atti del III Colloquio Internazionale di Dialettologia Greca, Napoli-Fiaiano d'Ischia, 25-28 settembre 1996 (AION, 19; pp. 109-127). Napoli: Ist. Univ. Orientale.

Mycenaean Common Nouns in the Disguise of Proper Names. In S. Deger-Jalkotzy et al. (Eds.), Floreant Studia Mycenaea. Akten des X. internationalen mykenologischen Colloquiums in Salzburg vom 1.-5. Mai 1995 (Vol. 1; pp. 121-129). Wien: Verlag der Österreichischen Akademie der Wissenschaften.

Schriftsprache, Umgangssprache, Dialekt im Latein. In H. Petersmann, \& R. Kettemann (Eds.), Latin vulgaire - latin tardif $V^{e}$. Actes $d u \mathrm{~V}$. Colloque international sur le latin vulgaire et tardif, Heidelberg, 5-8 Septembre 1997 (pp. 89-98). Heidelberg: Universitätsverlag C. Winter.

\section{0}

Die ägäischen voralphabetischen Schriften. In Y. Nishina (Ed.), Europa et Asia Polyglotta Sprachen und Kulturen. Festschrift für Robert Schmitt-Brandt (pp. 7-12). Dettelbach: Röll.

Rozhovor s PhDr. Antonínem Hartmannem, CSc., u příležitosti jeho 90. narozenin. Univerzitni noviny, 7, 2000(3), 62-64 (with J. Nechutová).

The Present Situation and Future Tasks of Ancient Greek Dialectology. In Studies in Greek Linguistics. Proceedings of the 20th Annual Meeting of the Department of Linguistics, Faculty of Philosophy, Aristotle University of Thessaloniki, 23-25 April 1999 [Meletes gia tēn hellēnikè glōssa: Praktika tês $20^{e ̀ s}$ etêsias synantēsès tou Tomea Glōssologias tês Philosophikēs Scholēs tou Aristoteleiou Panepistēmiou Thessalonikēs, 23-25 Apriliu 1999] (pp. 19-32). Thessaloniki: Aristotle University.

\section{1}

Alla memoria di John Chadwick [On the Memory of John Chadwick] (Milano, 5 ottobre 1999). Acme, 54(3), 273-281.

Cesta k řecké abecedě. In A. Bartoněk et al. (Eds.), Vademecum Graeco-Latinum Brunense. Sbornik vydán u př́ležitosti setkáni učiteli̊ klasických jazyků, 7.-8. prosince 2001 (pp. 19-44). Brno: Ústav klas. studií FF MU.

La posizione del miceneo nel quadro dei dialetti greci. In C. Consani, \& L. Mucciante (Eds.), Norma e variazione nel diasistema greco. Atti del quarto Incontro internazionale di linguistica greca, Chieti-Pescara, 30 settembre - 2 ottobre 1999 (pp. 53-62). Alessandria: Edizioni dell'Orso.

\section{2}

Mycenaean Words in Homer. In Ch. Clairis (Ed.), Recherches en linguistique grecque I, Actes du $5^{e}$ Colloque international de linguistique grecque, Sorbonne, 13-15 septembre 2001 (pp. 91-94). Paris: L'Harmattan. 


\section{3}

Handbuch des mykenischen Griechisch. Heidelberg: C. Winter.

Čtvero zastavení s Jendou Firbasem. In J. Kroupa, \& L. Urbanová (Eds.), Jan Firbas ve vzpominkách (Opera Universitatis Masarykianae Brunensis, Facultas philosophica, 343; pp. 63-65). Brno: Masarykova univerzita.

Makarónská poezie. In A. Bartoněk, \& K. Pořízková (Eds.), Vademecum Graeco-Latinum Brunense. Sbornik vydán u přiležitosti setkáni učitelů klasických jazyků, 21.-22. března 2003 (pp. 5-8). Brno: Ústav klas. studií FF MU.

\section{4}

40 let od smrti profesora dr. Františka Novotného [The 40th Anniversary of the Death of Professor dr. František Novotný]. Universitas. Revue Masarykovy univerzity, 2004(3), 16-17.

Il „manuale del greco miceneo“. In G. Rocca (Ed.), Dialetti, dialettismi, generi letterari e funzioni sociali. Atti del V Incontro Internazionale di Linguistica Greca, Milano, 12-13 settembre 2002 (Ellada: Collana di storia linguistica della Grecia e del Mediterraneo orientale, 1; pp. 121-142). Alessandria: Edizioni dell'Orso.

K rozluštění mykénské řečtiny. In A. Bartoněk, \& K. Pořízková (Eds.), Vademecum Graeco-Latinum Brunense. Sbornik vydán u přiležitosti setkáni učitelů latiny a řečtiny v roce 2004 (pp. 5-14). Brno: Ústav klas. studií FF MU.

Lingvistické práce v brněneské klasické filologii v poválečných letech 1945-2003. Sbornik praci Filozofické fakulty brněnské univerzity, N 9 (Graeco-Latina Brunensia), 5-13.

Vývoj latiny a její vztah k jiným jazykům. In A. Bartoněk, \& K. Pořízková (Eds.), Vademecum Graeco-Latinum Brunense. Sbornik vydán u př́ležitosti setkáni učitelů latiny a řečtiny v roce 2004 (pp. 15-24). Brno: Ústav klas. studií FF MU.

Viparelli, V. (Ed.). (2003). Tra strategie retoriche e generi letterari: Dieci studi di letteratura latina. Napoli: Liguori Editore. (Rev.). Sbornik praci Filozofické fakulty brněnské univerzity, $N 9$ (Graeco-Latina Brunensia), 174-176 (with D. Bartoňková).

\section{6}

Aspekte des Lexikons der neuesten Theben-Texte. In S. Deger-Jalkotzy, \& O. Panagl (Eds.), Die neuen Linear B-Texte aus Theben: Ihr Aufschlusswert für die mykenische Sprache und Kultur. Akten des internationalen Forschungskolloquiums an der Österreichischen Akademie der Wissenschaften am 5. und 6. Dezember 2002 (pp. 11-18). Wien: Verlag der Österreichischen Akademie der Wissenschaften.

Classical and Vulgar Latin and Greek: Some Problems to be Solved. In C. Arias Abellán (Ed.), Latin vulgaire - latin tardif. Actes du VII. ${ }^{\text {eme }}$ Colloque international sur le latin vulgaire et tardif, Séville, 2-6 septembre 2003 (pp. 81-88). Sevilla: Universidad de Sevilla.

Indoevropské jazyky západního pobřeží Malé Asie. In A. Bartoněk, \& K. Pořízková (Eds.), Vademecum Graeco-Latinum Brunense. Sbornik vydán u přiležitosti konference „Staré indoevropské jazyky“, Brno, 10. 5. 2005 (pp. 5-15). Brno: Ústav klas. studií FF MU.

\section{7}

Písmo a jazyk mykénské řečtiny (1400-1200 př. Kr.). Brno: Masarykova univerzita. 
Zwei Dimensionen in der mykenischen Dialektologie. In I. Hajnal, \& B. Stefan (Eds.), Die altgriechischen Dialekte. Wesen und Werden. Akten des Kolloquiums Freie Universität Berlin, 19.-22. September 2001 (pp. 19-27). Innsbruck: Institut für Sprachen und Literaturen der Universität Innsbruck.

\section{8}

Řecko-latinská syntax v evropském kontextu (Opera Universitatis Masarykianae Brunensis, Facultas Philosophica, 375). Brno: Masarykova univerzita.

Different Trends of Development in Latin and Ancient Greek Syntax. In R. Wright (Ed.), Latin vulgaire - latin tardif. Actes du VIII'me Colloque international sur le latin vulgaire et tardif, Oxford, 6-9 Septembre 2006 (pp. 26-33). Hildesheim-Zürich-New York: Georg Olms Verlag.

Greek Lexical Elements in the Linear B Proper Names. In A. Veiga, \& M. I. González Rey (Eds.), La diversité linguistique. Actes du XXXI ${ }^{e}$ Colloque de la Société internationale de linguistique fonctionnelle, Lugo, 11-15 septembre 2007. Lugo: Axac Editorial.

Řecko-latinská syntax v globálním pohledu. In B. Pokorná (Ed.), Netradični př́stupy $k$ výuce klasických jazyků. Sbornik z konference konané v rámci projektu FRVŠ 2007 Propagace výuky latinského jazyka, řšeného na Katedře klasické fllologie FF UP v Olomouci (pp. 40-46). Olomouc: Univerzita Palackého. [Online available at the website of the Department of Classical Philology, Palacký University, Faculty of Arts, Olomouc; vid. 17. 11. 2016, http://www.kkf.upol.cz/prilohy/netradicni_pristupy_k_vyuce_klasickych_jazyku.pdf].

The Lexical Elements in the Mycenaean Compounds. In A. Sacconi et al. (Eds.), Colloquium Romanum, vol. I, Atti del XII colloquio internazionale di micenologia, Roma, 20-25 febbraio 2006 (pp. 53-75). Pisa-Roma: Fabrizio Serra.

\section{9}

Dialekty klasické réttiny (Opera Universitatis Masarykianae Brunensis, Facultas Philosophica, 381). Brno: Masarykova univerzita.

Comparative Graeco-Latin Sentence Syntax in the European Context. In K. Loudová, \& M. Žáková (Eds.), Early European Languages in the Eyes of Modern Linguistics. Proceedings of the Colloquium on the Ancient Indo-European Languages and the Early Stages of the Modern Romance, Germanic and Slavonic Languages, Brno, 28 September - 1 October 2008 (pp. 23-35). Brno: Masarykova univerzita.

Řecké literární dialekty [Dialects of Ancient Greek Literature]. In K. Petrovićová, \& I. Radová (Eds.), Erant in quadam civitate... Na počest Daši Bartoňkové (Graeco-Latina Brunensia, 14, 1-2; pp. 19-30). Brno: Masarykova univerzita.

\section{0}

A Comparative Graeco-Latin Sentence Syntax within the European Context (LINCOM studies in Indo-European linguistics, 37). München: Lincom Europa (Transl. from the Czech edition Řecko-latinská syntax v evropském kontextu. Brno: Masarykova univerzita 2008).

Latina pro posluchače Filozofické fakulty (11. ed., 1. reprint). Brno: Masarykova univerzita. Deontická a epistémická modalita v latině a řečtině. Třicet pět let výzkumné práce na 
Masarykově univerzitě. In A. Bičan, J. Klaška, P. Macurová, \& J. Zmrzlíková (Eds.), Karlik a továrna na lingvistiku. Prof. Petru Karlikovi k šedesátým narozeninám (pp. 29-39). Brno: Host, Masarykova univerzita.

Latina by si zasloužila významnější postavení (interview). Muni.cz. Měsičník Masarykozy univerzity, březen 2010, 7 (with D. Povolný). [Online available at https://www.online. muni.cz/veda-a-vyzkum/1785-bartonek-latina-by-si-zaslouzila-vyznamnejsi-postaveni; vid. 17. 11. 2016].

Významné osobnosti naší univerzity: Antonín Hartmann. Universitas. Revue Masarykozy univerzity, 2010(1), 60-62.

\section{1}

Chréstomatie starořeckých nářečnich nápisů (Opera Universitatis Masarykianae Brunensis, Facultas Philosophica, 403). Brno: Masarykova univerzita.

Personal Considerations in EWHUM. In F. Tarantino et al. (Eds.), Ewhum: European Humanism in the World (pp. 53-54). Modugno (Ba): Favia.

\section{2}

Poznámky ke starořeckým dialektům se zaměřením na hláskové a morfologické diferenční jevy ve vztahu k attičtině. Starořecké dialekty v očích Athéňana. In I. Radová, \& D. Urbanová (Eds.), Sbornik na počest Jarmily Bednař́kové (Graeco-Latina Brunensia, 17, 2; pp. 229-235). Brno: Masarykova univerzita.

Vycpaný zajíc v 2. C, magnetofon prvobytně pospolný a všehochut' o starořeckém světě. In M. Horáková, \& M. Plešák (Eds.), Jubilejni benefice pro Artura Závodského. Sbornik ke 100. výroči narozeni prof. PhDr. Artura Závodského, DrSc. (pp. 15-16). Brno: Masarykova univerzita.

\section{3}

Repertory of Sites Yielding Linear B Documents. Eirene: Studia Graeca et Latina Paulo Oliva nonagenario dicata, 49(1-2), 77-79.

\section{4}

Indoevropské laryngály a jejich řecké a latinské střídnice. In K. Petrovićová, \& L. Švanda (Eds.), Sbornik na počest Eleny Marečkové (Graeco-Latina Brunensia, 18, 2; pp. 217-237). Brno: Masarykova univerzita.

Půl století od konce životní dráhy prof. dr. Františka Novotného. Universitas. Revue Masarykovy univerzity, 2014(3), 50-51.

\section{5}

Chrestomathy of Ancient Greek Dialects Inscriptions (LINCOM Studies in Indo-European Linguistics, 45). Munich: Lincom.

Four Encounters with Jenda Firbas. In M. Černý, J. Chamonikolasová, \& E. Golková (Eds.), Collected Works of Jan Firbas, III: 1979-1986 (pp. 8-9). Brno: Masaryk University Press.

Výbor textowých ukázek z rané řecké epické poezie s úvodem do rané řecké epiky a homérského jazyka (with Z. Kubík; unpublished teaching material at the Department of Classical Studies, Masaryk University, Faculty of Arts, Brno). 
Duhoux, Y., \& Morpurgo Davies, A. (2008, 2011). A Companion to Linear B: Mycenean Greek Texts and World, 1-2. Louvain-la-Neuve: Peeters. (Rev.). Graeco-Latina Brunensia, 20, 2015(2), 202-210.

Duhoux, Y. (2013). Le mycénien (Études Anciennes, 53; Paradeigmata: Recueil d'Inscriptions Grecques Dialectales, I, Association pour la Diffusion de la Reserche sur l'Antiquité /A.D.R.A./). Nancy-Paris: de Boccard. (Rev.). Graeco-Latina Brunensia, 20, 2015(2), 210-211.

\section{6}

André Martinet's „Économie des changements phonétiques“ as Stimulus for an Ancient Greek Phonemic Analysis. In Z. Raková, Ch. G. L. Cusimano, \& A. Podhorná-Polická (Eds.), Actes du XXXV colloque international de linguistique fonctionnelle, Brno, 18-22 septembre 2013 (pp. 9-13). Brno: Masarykova univerzita.

Rozluštění, které přidalo pět století k raným dějinám Řeků (Přednáška prof. PhDr. Antonína Bartoňka, DrSc., oceněného v roce 2003 Cenou rektora v kategorii „Významný tvůrčí čin“, která byla přednesena u příležitosti Akademického dne 19. května v roce 2004 na Právnické fakultě Masarykovy univerzity). Universitas. Revue Masarykovy univerzity, 2016(2), 3-7.

Trocha řecko-latinských etymologií neuškodí. Graeco-Latina Brunensia, 21, 2016(1), 151162.

\section{In print}

Encheiridio tés mykénaikés hellenikés glóssés. Thessaloniki: Aristotelous University of Thessaloniki, Triandafyllidis Foundation (Transl. from the German edition Handbuch des mykenischen Griechisch. Heidelberg: C. Winter 2003).

Introduction; Mycenaean Greek. In A. Bartoněk, \& Ch. Tzitzilis (Eds.), A $\rho \chi \alpha i \varepsilon \varsigma$ $\varepsilon \lambda \lambda \eta \nu \iota \kappa \varepsilon ́ \varsigma \delta \iota \alpha ́ \lambda \varepsilon \kappa \tau o \iota$ [Archaies ellinikes dialektoi; Ancient Greek Dialects]. Thessaloniki: Aristotelous University of Thessaloniki, Triandafyllidis Foundation.

The Degree of Recognizing Immediately a Concrete Ancient Greek Dialect in the Speech of Native Speakers. In A. Panayotou, \& G. Galdi (Eds.), Hellènikes dialektoi ston archaio kosmo. Actes du VI Colloque international sur les dialectes grecs anciens, Nicosie, Université de Chypre, 26-29 septembre 2011 (Bibliothèque des Cahiers de Linguistique de Louvain, BCLL 137). Louvain: Peeters Publishers.

Sestavily Anna a Marie Žákovy 
